\title{
Developing Graduate TPACK Capabilities in Initial Teacher Education Programs: Insights from the Teaching Teachers for the Future Project
}

\author{
Glenn Finger - Geoff Romeo - Margaret Lloyd • Deborah Heck • \\ Trudy Sweeney • Peter Albion • Romina Jamieson-Proctor
}

Published online: 6 January 2015

(C) De La Salle University 2015

\begin{abstract}
There is increased accountability of initial teacher education (ITE) programs in Australia to develop Graduate teachers who are better prepared. Most ITE programs have been designed using Pedagogical Content Knowledge. Informed by the growing Technological Pedagogical Content Knowledge (TPACK) research, this journal article suggests that ITE programs need to develop Graduate teachers who have the TPACK capabilities to use technologies to support teaching and student learning. Insights from the research and evaluation of the Teaching Teachers for the Future (TTF) Project, which was guided by the TPACK conceptualisation, are provided. The TTF Project, which involved all Higher Education Institutions providing ITE programs in Australia, drew upon the TPACK conceptualisation. The TTF Project research and
\end{abstract}

The Teaching Teachers for the Future (TTF) Project was funded by the Australian Government Department of Education, Employment and Workplace Relations (DEEWR) through the ICT Innovation Fund. The author was the Chair, Research and Evaluation Working Group of the TTF Project.

G. Finger $(\bowtie)$

Griffith Institute for Educational Research, Griffith University,

Brisbane, QLD, Australia

e-mail: g.finger@griffith.edu.au

G. Romeo

Australian Catholic University, Melbourne, Australia

e-mail: geoff.romeo@acu.edu.au

\section{Lloyd}

Queensland University of Technology, Brisbane, Australia

e-mail: mm.lloyd@qut.edu.au

D. Heck

University of the Sunshine Coast, Sippy Downs, QLD, Australia

e-mail: dheck@usc.edu.au evaluation included the development and administration of a TTF TPACK Survey and the implementation of the Most Significant Change Methodology. Key findings resulting from the employment of these methodologies are summarised to provide guidance to inform the improvement of ITE programs to develop Graduate TPACK capabilities.

Keywords Teaching Teachers for the Future Project . TPACK · Graduate teachers · Professional standards · Most significant change

\section{Introduction}

This journal article focuses on initial teacher education (ITE) programs in Australia. ITE programs are offered in 48 institutions, and predominantly in public universities $(n=37,77.08 \%)$. There are a number of paths to becoming a teacher in Australia with the majority of preservice teachers electing to undertake four-year programs, typically leading to a Bachelor of Education. Others, if

\footnotetext{
T. Sweeney

Flinders University, Adelaide, SA, Australia

e-mail: trudy.sweeney@flinders.edu.au

P. Albion

University of Southern Queensland, Toowoomba Campus,

Toowoomba, QLD, Australia

e-mail: peter.albion@usq.edu.au

R. Jamieson-Proctor

Australian Catholic University, Brisbane, QLD, Australia

e-mail: romina.jamieson-proctor@acu.edu.au
} 
eligible, choose graduate entry programs which might be a Graduate Diploma of Education or a Master of Teaching program. These vary in the volume of learning ranging from 12 to 24 months full-time study, offered in a teacher education institution, or, alternatively in an intensive program with employer support, such as Teach For Australia (Teach for Australia 2014). Since 2012, all modes of initial teacher preparation are subject to national accreditation. In recent times, ITE programs in Australia have been subject to increasing, and frequently contradictory, regulation (Lloyd 2013a, b, 2014).

The Australian Government believes that teacher quality is critical to the future prosperity of young Australians and the productivity of the nation. Consequently, there is increased accountability of ITE programs to develop Graduate teachers who are better prepared. To illustrate, a Teacher Education Ministerial Advisory Group (TEMAG) was established in 2014 to provide advice to the Australian Government on "how teacher education programmes could be improved to better prepare new teachers with the practical skills needed for the classroom" (Teacher Education Ministerial Advisory Group 2014, p. 2).

The importance and scale of developing Technological Pedagogical Content Knowledge (TPACK) graduate capabilities through quality ITE programs is evident in the Teacher Education Ministerial Advisory Group Issues Paper (Teacher Education Ministerial Advisory Group 2014) which stated that, "In 2012, there were around 76,000 domestic students pre-service teachers enrolled in these programmes-62,000 in undergraduate programmes and 14,000 in postgraduate programmes" (Teacher Education Ministerial Advisory Group 2014, p. 5). The issues paper acknowledged that there have been numerous reviews of teacher education in most Australian jurisdictions in the past two years, including:

- New South Wales-Great Teaching, Inspired learning: Blueprint for Action (New South Wales Government Education and Communities 2014)

- Victoria-From New Directions to Action: World class teaching and school leadership (Victoria Department of Education and Early Childhood Development 2013)

- Queensland-A Fresh Start: Improving the preparation and quality of teachers for Queensland schools (Department of Education, Training and Employment 2013)

- South Australia-Building a Stronger South Australia: High Quality Education (Government of South Australia 2013)

A search of those review documents finds little or no reference to TPACK. Thus, this journal article, situated within this teacher quality agenda, argues that it is critically important that ITE programs develop Graduate teachers who have the TPACK capabilities to use technologies to support teaching and student learning. After discussion of the Australian Professional Standards for Teachers (AITSL 2011a) in relation to TPACK capabilities, insights into key findings from the research and evaluation of the Teaching Teachers for the Future (TTF) Project are provided.

The TTF Project, which involved all Higher Education Institutions providing ITE programs in Australia, drew upon the TPACK conceptualisation. At the final TTF Project National Support Network meeting in Melbourne, Australia in March 2012, Punya Mishra, as keynote speaker, stated that "This project dwarfed any TPACK initiatives happening internationally". The TTF Project research and evaluation included the development and administration of a TTF TPACK Survey and the implementation of the Most Significant Change Methodology (MSC). Key findings resulting from the employment of these methodologies are summarised to provide guidance to inform the improvement of ITE programs to develop Graduate TPACK capabilities.

\section{TPACK and the Australian Professional Standards for Teachers}

The accreditation of ITE programs in Australia is governed by the Australian Institute of Teaching and School Leadership (AITSL). Of particular importance in this process are two core frameworks, namely, the Australian Professional Standards for Teachers (AITSL 2011a) and the Accreditation of ITE Programs in Australia: Standards and Procedures (AITSL 2012). These standards "make explicit the knowledge, skills and attributes of graduates of nationally accredited programs" (AITSL 2011a, p. 3). Focusing on the graduate level, the TPACK framework guided the TTF Project which sought to enhance graduate TPACK confidence and capabilities in Australian ITE programs.

Shulman (1986) noted that knowledge of content (CK) and pedagogy $(\mathrm{PK})$ was not sufficient, but that teachers also required Pedagogical Content Knowledge (PCK), which informs strategic decisions about how best to represent content for effective learning in a given context. Although teachers have always used appropriate technologies, such as blackboards, overhead projectors, and whiteboards to support pedagogy, ICT has presented particular challenges constituting a "wicked problem" (Mishra and Koehler 2007), which is complex with little agreement about solutions. Mishra and Koehler (2006) argued that ICT has changed the classroom context sufficiently that it should be recognised by expanding Shulman's concept of PCK to include technological knowledge 


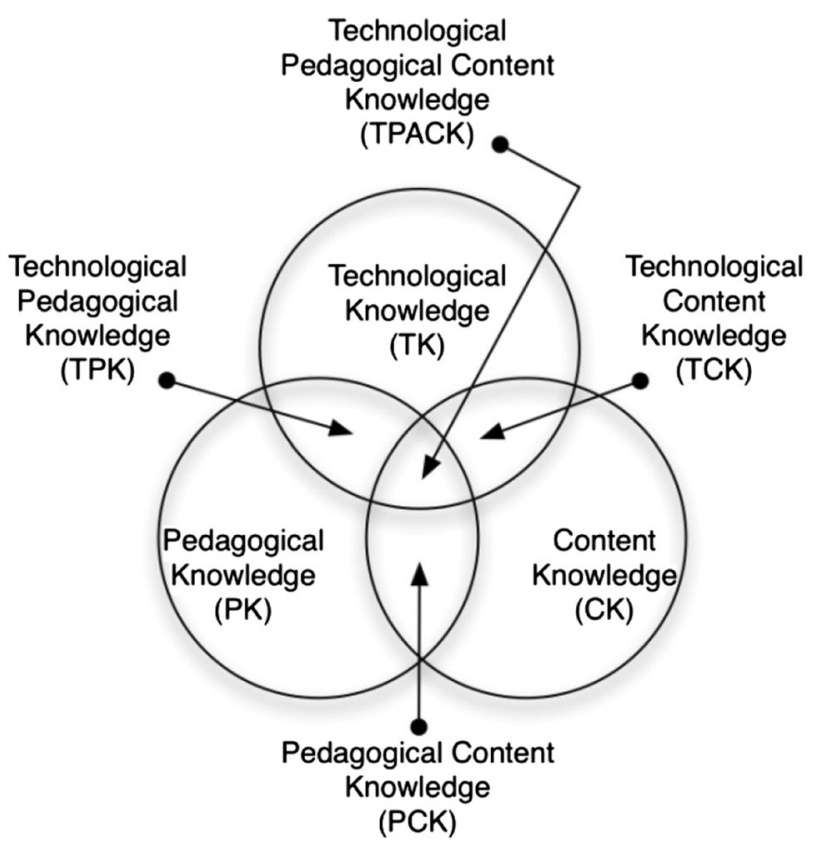

Fig. 1 Technological Pedagogical Content Knowledge (TPACK) [after Mishra and Koehler (2006)]

(TK), as shown in Fig. 1. It is where TK intersects with CK and PK that represents TPACK (Thompson and Mishra 2007, p. 38).

Elsewhere, research (Tearle and Golder 2008; Sang et al. 2010; Tondeur et al. 2012) has reported that "beginning teachers feel they are not well-prepared to effectively use technology in their classrooms" (Tondeur et al. 2012, p. 134). Thus, ITE programs need to better prepare future teachers to effectively engage with the wicked problem of teaching and technologies. While AITSL does not explicitly refer to TPACK, these standards and the ICT priority area are arguably requiring TPACK capabilities for Graduate teachers to develop and demonstrate. An outcome of the TTF Project was the development of ICT elaborations for Graduate Teachers (AITSL 2011b). To illustrate, an example is provided in Table 1 for some aspects of Standard 2.teach specific subject areas

In Troubled times in teacher education in Australia: 2012-2013, Lloyd (2013a) suggests that there is a need to reconsider the use of the Australian Professional Standards for Teachers (AITSL 2011a) and their integral role in the Accreditation of ITE Programs in Australia: Standards and Procedures (AITSL 2012, 2013). Specifically, Lloyd (2013a) identified that "Teacher education is premised on the concept of PCK (Shulman 1986, 1987) and more recently, TPACK (Mishra and Koehler 2006)" (p. 60). This is strongly supported by Agyei and Voogt (2011), Drent and Meelissen (2008) who have argued that a "crucial factor influencing new teachers' adoption of technology is the quantity and quality of pre-service technology experiences included in their teacher education programmes" (Tondeur et al. 2012, p. 134).

The following section summarises features of the TTF Project, including the research and evaluation, and key findings.

\section{Teaching Teachers for the Future Project}

The TTF Project was a 15-month long, $\$ 8$ million project, funded by the Australian Government's ICT Innovation Fund. The lead agency was Education Services Australia (ESA), with partners being the Australian Council of Deans of Education (ACDE), the Australian Institute for Teaching and School Leadership (AITSL), and the Australian Council for Computers in Education (ACCE), and involved 39 Australian Higher Education ITE providers. It aimed to develop the ICT capabilities of future teachers and, therefore, it focused on "systematic change in the ICT proficiency of graduate teachers in Australia by building the ICT capacity of teacher educators and developing resources to provide rich professional learning and digital exemplar packages" (Australian Government 2010, p. 1).

Collaboration was enabled through the TTF National Support Network (NSN), and the formation of the TTF Research and Evaluation Working Group. The TPACK conceptualisation (Mishra and Koehler 2006, 2008) guided the project and it was also informed by the Australian Professional Standards for Teachers (AITSL 2011a). As indicated earlier, these standards for Graduate Teachers were built upon to develop the ICT Elaborations for

Table 1 Standard 2-example from ICT elaborations for graduate teachers (AITSL 2011b)

\begin{tabular}{lll}
\hline Standard 2: Know the content and how to teach it & ICT elaboration \\
\hline Focus area & Descriptor & $\begin{array}{l}\text { Demonstrate knowledge and understanding of the } \\
\text { concepts, substance and structure of the content and } \\
\text { teaching strategies of the teaching area }\end{array}$ \\
$\begin{array}{l}\text { 2.1 Content and teaching } \\
\text { strategies of the teaching } \\
\text { area }\end{array}$ & $\begin{array}{r}\text { Demonstrate knowledge and understanding of ways that } \\
\text { the use of digital resources and tools can complement } \\
\text { teaching strategies and promote deep learning of, and } \\
\text { engagement with, the content of specific teaching areas }\end{array}$ \\
$\begin{array}{l}\text { Organise content into an effective learning and teaching } \\
\text { organisation }\end{array}$ & $\begin{array}{r}\text { Demonstrate the ability to select and organise digital } \\
\text { content in relation to relevant curriculum }\end{array}$ \\
\hline
\end{tabular}


Graduate Teachers (AITSL 2011b) which made TPACK capabilities more explicit in relation to the Australian Professional Standards for Teachers (AITSL 2011a).

\section{Research Design and Methodology}

The TTF Project sought to measure changes in the TPACK confidence and capabilities of the ITE students. Three major research and evaluation strategies were designed and implemented; namely, (1) the development and administration of a TTF TPACK Survey, (2) the implementation of Most Significant Change (MSC) methodology, and (3) the facilitation of and opportunities for institution-initiated TTF Project research and evaluation projects.

The development of TTF TPACK Survey instrument has been outlined elsewhere (Jamieson-Proctor et al. 2013). The TTF TPACK Survey aimed to measure the change in aspects of pre-service teachers' TPACK as a result of their involvement in the TTF Project intervention conducted throughout 2011. This was informed the TPACK Confidence Survey (TCS) (Albion et al. 2010), based on its theoretical framework and psychometric properties. The TTF TPACK Survey incorporated additional items to extend the TCS, in order to meet the particular needs of the TTF Project.

The survey instrument focused on the TPACK elements, namely TPK, TCK and TPACK. The 20-item scale of the original TCS which probed TPACK was extended with four items describing how pre-service teachers might support future school students' use of ICT in the curriculum. An additional set of 24 items was created to specifically explore ITE students' TPK and TCK. The ITE students were asked to rate both their perceived level of confidence with ICT, as well as their perceived level of usefulness of ICT to undertake the task described by each item. The survey provided 7 substantive response options (0123456) with provision for an, 'Unable to Judge' response. Only three (of 7) response options were labelled; namely, 0-Not confident/useful; 3-Moderately confident/useful; and 6-Extremely confident/useful.

The TTF TPACK Survey was administered online pre(T1) and post-(T2) the TTF intervention in each HEI to seek evidence of changes to the pre-service teachers' selfperceptions of their confidence to use ICT with a range of pedagogical strategies, and to support their future students' learning with ICT. Additionally, it aimed to measure the pre-service teachers' perceptions of usefulness of ICT for teaching and learning. The TTF TPACK Online Survey data collections were conducted in mid-June and early November 2011.The data collected were subject to complementary analysis procedures using both the pre $(N=12,881)$ and post $(N=5,809)$ data.
In addition, the MSC methodology (Dart and Davies 2005) employed at each HEI provided a mechanism for those involved in the project to analyse the impact of the work and chart the learning. The implementation and findings of the Most Significant Change (MSC) methodology are presented elsewhere in Using Most Significant Change Stories to document the impact of the Teaching Teachers for the Future Project: An Australian Teacher Education Story (Heck and Sweeney 2013). Three domains of change were selected as the focus for reflection and learning: teacher educator use of ICT curriculum, pedagogy, assessment and resources in specific curriculum areas; ICT capacity of teacher educators and ICT capacity of pre-service teachers. The research questions that formed the focus of this MSC approach were:

- To identify the patterns within most significant change stories related to the development of ICT curriculum, pedagogy, assessment and resource use in Mathematics, Science, English and History curriculum in teacher education courses; and

- To identify the patterns within most significant change stories related to the development of teacher educator and pre-service teachers' ICT capacity.

\section{TTF TPACK Survey Findings}

This section provides a summary of key findings, with more extensive findings reported elsewhere, such as Finger et al. (2013) in providing a summary of key findings from the TTF TPACK Survey, while Heck and Sweeney (2013) provide insights into the MSC across three domains of change: Course development, ICT capacity of teacher educators and ICT capacity of pre-service teachers. In relation to the institution-initiated TTF Project research and evaluation projects, extensive publications have emanated from this approach (see, for example, Campbell 2013; Chandler and Redman 2013; Doyle and Reading 2013; Gronn et al. 2013; Henderson et al. 2013; Kearney and Maher 2013; Lloyd and Mukherjeee 2013; Sweeney and Drummond 2013).

Parametric and Rasch analyses of the TTF TPACK Survey data were undertaken. Four scales were investigated and confirmed as reliable: (1) Confidence-teacher items; (2) Usefulness-teacher items; (3) Confidence-student items; and (4) Usefulness—student items. Importantly, the samples report substantive and statistically significant increases in Confidence with using IT sub-scales, both "for you as a teacher" and "for your future students, from responses obtained from the administration of the TTF TPACK Survey in Semester 12011 (T1) and the data obtained at the end of Semester 22011 (T2); i.e. 
- The scale: Confidence to use ICT as a teacher showed measurable growth across the whole scale from T1 to T2.

- The scale: Confidence to facilitate student use of ICT also showed measurable growth across the whole scale from $\mathrm{T} 1$ to $\mathrm{T} 2$.

- The scale: Usefulness of ICT for ITE students as a future teacher showed no change from T1 to T2.

- The scale: Usefulness of ICT for ITE students for their future students showed no change from T1 to T2.

As reported by Finger et al. (2013), the analysis of the four sets of data using the individual HEI as the unit of analysis found marked differences from the national project results for those universities tested. However, the measurable growth in confidence to use ICT as a teacher, and to facilitate student use of ICT, provided evidence that the TTF Project using the TPACK conceptualisation impacted positively on ITE students. Specifically, as TPACK relates directly to pedagogical knowledge, improved confidence to use ICT to support teaching and to facilitate student use of ICT reflects improved efficacy for pedagogical improvements of the ITE students. Moreover, while no change was identified in relation to the usefulness items, students generally indicated strong agreement to these as being useful when they completed the first (T1) TTF TPACK Survey. The following sections summarise key overall findings.

\section{Confidence and Usefulness: ICT to Support Teaching}

Based on responses to confidence items, participants were most likely to be confident that ICT would support teaching in relation to:

- use a range of ICT resources and devices for professional purposes;

- $\quad$ select and use a variety of digital media and formats to communicate information, collaborating for professional purposes such as online professional communities;

- select and organise digital content and resources;

- use ICT for reporting purposes such as reporting to parents/carers;

- teach specific subject areas in creative ways; and

- engage with colleagues to improve professional practice.

In contrast, they were least likely to:

- be confident ICT would support teaching in relation to supporting students from Aboriginal and Torres Strait Islander backgrounds;

- manage challenging student behaviour by encouraging responsible use of ICT;

- develop digital citizenship to promote student demonstration of rights and responsibilities in use of digital resources and tools;
- engage parents and families in the child's school through ICT; and

- teach strategies responsive to diverse student backgrounds.

Based on responses to usefulness items, participants were most likely to consider that ICT would usefully support teaching in relation to:

- demonstrate knowledge of a range of ICT to engage students;

- teach strategies responsive to students' learning styles;

- design ICT activities that enable students to become active participants in own learning;

- teach specific subject areas in creative ways; and

- access, record, manage and analyse student assessment data.

In contrast, participants were least likely to:

- consider that ICT would usefully support teaching in relation to managing challenging student behaviour by encouraging responsible use of ICT;

- engage parents and families in the child's school through ICT;

- teach strategies to support students from Aboriginal and Torres Strait Islander backgrounds;

- consider the usefulness of digital citizenship to promote student demonstration of rights and responsibilities in use of digital resources and tools;

- reflect on relevant ICT research to inform professional practice; and

- identify personal and professional learning goals in relation to using ICT.

In summary, while improved confidence was reported more generally, there remain significant challenges which are expected in terms of TPACK capabilities of graduate teachers. Specifically, there remain challenges in pre-service students understanding and having the confidence to develop and demonstrate digital citizenship, develop approaches using ICT in managing student behaviour, and to engage more effectively with parents. The ITE students remain particularly challenged in supporting students from Aboriginal and Torres Strait Islander backgrounds, which is an extremely important challenge in Australian schooling which needs to improve equity in schooling outcomes.

\section{Confidence and Usefulness: ICT Supports Student Learning}

Based on responses to items asking them how confident they were that they had the knowledge, skills and abilities to support students' use of ICT for learning, they were most likely to be confident to: 
- provide motivation for curriculum tasks, demonstrating what they have learned; and

- develop understandings of the world, gathering information and communicating with a known audience, and communicating with others locally and globally.

In contrast, they were least likely to be confident that they had the knowledge, skills and abilities to support students' use of ICT for learning in relation to:

- facilitate integration of curriculum areas to construct multidisciplinary knowledge, understanding and participating in a changing knowledge economy;

- $\quad$ synthesise their knowledge;

- acquire awareness of global implications of ICT-based technologies; and

- develop functional competencies in specified curriculum areas.

Based on responses to items asking them how useful they considered it would be for them as a teacher to ensure students' use of ICT for learning, they were most likely to be confident to:

- engage in independent learning through access to education at time, place and pace of their own choosing;

- develop an understanding of the world;

- demonstrate what they have learned; and

- acquire knowledge, skills, abilities and attitudes to deal with technological change.

In contrast, they were least likely to:

- feel that ICT would be useful for students' use of ICT for learning in relation to understanding and participating in the changing knowledge economy;

- critically evaluate their own and society's values;

- critically interpret and evaluate the worth of ICT-based content for specific subjects;

- gain intercultural understanding;

- feel that ICT was useful for students in acquiring awareness of global implications of ICT-based technologies;

- facilitate integration of curriculum areas to construct multidisciplinary knowledge; and

- develop functional competencies in specified curriculum areas.

In summary, students generally had improved in confidence in using ICT to support student learning, and that they generally believed that ICT was useful. However, there are identifiable implications for strengthening ITE programs in those areas where the pre-service students expressed less confidence, such as multidisciplinary knowledge, and dealing with a changing knowledge economy. As some of these students are likely to be teaching during significant future technological changes, further attention needs to be given to programs which develop those capabilities.

Using TPACK as the guiding conceptualisation together with the Australian Professional Standards for Teachers and ICT as a priority, ITE programs can further improve the confidence of pre-service teachers to use ICT to support teaching and to support student learning. The TTF Project provided guidance that improved confidence could be achieved, while identifying areas where considerable improvements are needed.

\section{Most Significant Change Stories}

The data analysis of the Most Significant Change stories identified the pattern of change and engagement across the 41 examples of TPACK implementation within curriculum courses in English, mathematics, science, history or a combination of learning areas. The data were analysed in two stages using different techniques. Two research questions were identified:

- What are the most significant changes described in the stories?

- What are the relationships between the concepts and themes reported in the stories?

The first stage involved the content analysis and the development of coding categories aligned with three domains of change, and sub-domains indicated in brackets. Stories could be coded across multiple domains and subdomains.

- ICT capacity of teacher educators-development of knowledge and understanding, confidence, and attitudes/beliefs;

- ICT capacity of pre-service teachers-development of knowledge and understanding, confidence, and attitudes/beliefs; and

- Course development-curriculum design, resources and assessment.

The key findings from the content analysis indicate that the most significant changes described in the stories primarily concerned the learning area of Mathematics and the development of pre-service teachers ICT capacity. In the learning area of Mathematics, the site of the most significant change concerned the domain of course development and the sub-domain of resources and curriculum design. Specifically, many stories described how a change to the course delivery and implementation was achieved through the inclusion of new technologies.

It was noted that the inclusion of new technologies was also an area of significant change in the learning area of Science. However, the site of most significant change 
concerned the development of pre-service teachers ICT capacity by increasing their TPACK, and their understandings, confidence, attitudes/beliefs related to the integration of tablets, laptops, online tools, specific software and interactive whiteboards into their practice.

In the learning area of History, the site of most significant change was divided equally between two domains: the ICT capacity of pre-service teachers, and course development. The majority of stories described how pre-service teachers' TPCK and understanding was developed, and assessment tasks were changed to incorporate relevant technologies.

The site of most significant change in the learning area of English also concerned two domains: ICT capacity of teacher educators and ICT capacity of pre-service teachers. The majority of stories reported an emphasis on developing the ICT knowledge and understandings of teacher educators and pre-service teachers.

In the category of 'other' that included courses, which incorporated one or more learning areas or represented an ICT specific course, the site of most significant change also concerned the two domains of ICT capacity of teacher educators and ICT capacity of pre-service teachers. The development of pre-service teachers' TPCK was reported in the majority of stories together with changes to attitudes and beliefs of pre-service teachers and teacher educators.

In summary, the content analysis suggests that the focus learning area of courses influenced the approach adopted to develop pre-service teachers' ICT capability. This is consistent with recent research which recommends that teachers' knowledge base be developed for specific subject domains (Cox and Graham 2009; Niess 2011; Voogt et al. 2013). In this study, the most significant changes related to the:

- Integration of new technologies in the delivery and implementation of mathematics courses;

- Development of pre-service teachers TPCK, and their understandings, confidence, attitudes/beliefs through the use of new technologies into learning activities in science courses;

- Development of pre-service teachers' TPCK and understandings of ICT, by incorporating relevant technologies into learning activities and assessment tasks in history;

- Development of both the TPCK and understandings of teacher educators and pre-service teachers in English courses; and

- Development of pre-service teachers' TPCK, and the attitudes and beliefs of pre-service teachers and teacher educators through ICT specialist courses and courses which focus on more than one learning area.
The second stage of data analysis involved using Leximancer 4 software to transform the natural language of the stories into semantic and relational maps (Smith and Humphreys 2006). This automated approach to content analysis identifies concepts on the basis of word frequency and co-occurrence within the text to identify a set of concepts. The text is then coded using the concepts identified at the level of 2 sentence blocks to produce a co-occurrence concept map. The automated nature of this approach removes the biases of data coded by an individual or group of researchers.

The Leximancer analysis explored the relationship between the concepts and themes identified from the Most Significant Change statement created for each story. This analysis indicated a strong focus on pre-service teacher 'confidence' as the main concept and theme. Further examination of the concept and theme mapping suggested a strong connection between confidence, knowledge, understanding and use of ICT that is supported by the content analysis where $83 \%$ of the stories focused on ICT capacity of pre-services teachers and $71 \%$ focused on course development.

As a theme, 'confidence' within the Leximancer analysis also demonstrated a complex level of interaction between all other themes. This suggests that the theme 'confidence' developed in conjunction with these other themes, for example, with 'learning', 'assessment' and 'use' illustrated the complexity of the relationship between all of the components of TPACK in teacher education and indicated that the development of pre-service teacher confidence plays a pivotal role.

\section{Conclusion and Recommendations of the Final Project Report}

The TTF Project, in demonstrating the usefulness of the TPACK conceptualisation for informing the design of ITE programs, has made a substantial contribution to the existing TPACK literature. Informed by the research and evaluation of the TTF Project, the Final Project Report listed recommendations for Australian Higher Education Institutions, for the Australian Government's Department of Education, Employment and Workplace Relations DEEWR), for the Australian Council of Deans of Education (ACDE), for expression of the ICT statements, and for developing future online professional learning resources. Directly relevant to this journal article are the following recommendations for Australian Higher Education Institutions and for the Australian Council of Deans of Education. 
Recommendations for Australian Higher Education Institutions

(1) Each Faculty or School responsible for Teacher Education should develop, maintain and add to on a regular basis, an easily accessible repository of resources to enable all staff (and students) to access these resources as necessary.

(2) Each Faculty or School responsible for Teacher Education should develop a leadership team to help staff to use these resources in a manner that is consistent with the TPACK model.

(3) Each Faculty or School responsible for Teacher Education should redesign certain key units to provide both a model of integrated ICT strategies and a model of effective redesign processes to form the basis of a broader redesign initiative across the school/faculty.

(4) Each Faculty or School responsible for Teacher Education should develop institutional processes/ systems to enable sustainable improvements in curriculum, pedagogy and assessment in relation to ICT dimensions, and graduates that can demonstrate the ICT dimensions of the National Standards for Graduate Teachers.

Recommendations for the Australian Council of Deans of Education (ACDE)

(1) ACDE should assume responsibility for sustaining facilitation of a collaborative national support network of ICT experts across Australian teacher education institutions. As part of this responsibility ACDE will encourage and support:

(a) Each Faculty or School responsible for Teacher Education should develop and share exemplary ICT pedagogy in one additional Australian curriculum area and in one cross-curriculum priority and generic capability statement.

(b) The development of informal State and Territory networks to ensure ICT elements of the Australian Curriculum include local content and technological priorities.

(c) Collaborative research in areas of need identified by the TTF Project evaluation.

This journal article has provided a summary of key findings from the research and evaluation of the TTF Project which was guided by the TPACK conceptualisation (Mishra and Koehler 2006, 2008) and involved all Australian Higher Education Institutions which provide ITE programs in Australia. The design of ITE programs can be informed from these findings which demonstrated measurable improvements in pre-service teacher confidence in using ICT to support teaching and to support student learning.

Importantly, the TTF Project confirmed that ITE programs in Australia need to move beyond Pedagogical Content Knowledge (PCK), as future teachers are expected to develop and demonstrate more than an understanding of the content and how to teach it. Rather, this project highlighted the importance of effectively preparing future teachers who have the TPACK capabilities needed for teaching in contexts characterised by dynamic and disruptive technological change and challenges.

\section{References}

Agyei, D. D., \& Voogt, J. M. (2011). Exploring the potential of the will, skill, tool model in Ghana: Predicting prospective and practicing teachers' use of technology. Computers \& Education, 56, 91-100.

Albion, P. R., Jamieson-Proctor, R., \& Finger, G. (2010). Auditing the TPACK Confidence of Australian Pre-Service Teachers: The TPACK Confidence Survey (TCS). In C. Maddux, D. Gibson, \& B. Dodge (Eds.), Research Highlights in Technology and Teacher Education 2010 (pp. 303-312). Chesapeake, VA: Society for Information Technology in Teacher Education.

Australian Government. (2010). Fact Sheet-Teaching Teachers for the Future: Building the ICTE capacity of pre-service teachers in Australian Institutions. Retrieved from http://www.deewr.gov. au/Schooling/DigitalEducationRevolution/DigitalStrategyforTea chers/Documents/TeachingTeachersfortheFuture.pdf.

Australian Institute for Teaching and School Leadership (AITSL). (2011a). The Australian Professional Standards for Teachers. Carlton South, Australia: Education Services Australia. Retrieved from http://www.aitsl.edu.au/australian-professionalstandards-for-teachers.

Australian Institute for Teaching and School Leadership (AITSL). (2011b). ICT Elaborations for Graduate Teachers. Retrieved from http://acce.edu.au/national-professional-standards-teachersict-elaborations-graduate-teachers.

Australian Institute for Teaching and School Leadership (AITSL). (2012). Accreditation of ITE programs in Australia: Guide to the accreditation process April 2012. Retrieved from http://www. aitsl.edu.au/verve/_resources/Guide_to_accreditation_process__April_2012.pdf.

Australian Institute for Teaching and School Leadership (AITSL). (2013). Accreditation of ITE programs in Australia: Guide to the accreditation process May 2013. Retrieved from http://www. aitsl.edu.au/docs/default-source/initial-teacher-education-resources/ guide_to_the_accreditation_process_file.pdf.

Campbell, C. (2013). Pre-service education students evaluating the TTF Mathematics Packages. Australian Educational Computing, Special Edition: Teaching Teachers for the Future Project., 27(3), 48-53.

Chandler, P., \& Redman, C. (2013). Teaching teachers for the future: Modelling and exploring immersive personal learning networks. Australian Educational Computing, Special Edition: Teaching Teachers for the Future Project., 27(3), 54-62.

Cox, S., \& Graham, C. (2009). An elaborated model of the TPACK framework. In I. Gibson, et al. (Eds.), Proceedings of Society for Information Technology \& Teacher Education International Conference 2009 (pp. 4042-4049). Chesapeake, VA: AACE. 
Dart, J., \& Davies, R. (2005). The 'Most Significant Change" (MSC) Technique: A guide to its use. Retrieved from http://www. clearhorizon.com.au/publication/the-most-significant-change-msctechnique/.

Department of Education, Training and Employment. (2013). A Fresh Start: Improving the preparation and quality of teachers for Queensland schools. Retrieved from http://flyingstart.qld.gov. au/SiteCollectionDocuments/A-Fresh-Start-strategy.pdf.

Doyle, H., \& Reading, C. (2013). Resistance to advocacy: Pre-service teachers recognising the potential of curriculum-based virtual worlds for TPACK-framed science teaching. Australian Educational Computing, Special Edition: Teaching Teachers for the Future Project., 27(3), 101-108.

Drent, M., \& Meelissen, M. (2008). Which factors obstruct or stimulate teacher educators to use ICT innovatively? Computers \& Education, 51, 187-199.

Finger, G., Albion, P., Jamieson-Proctor, R., Cavanagh, R., Grimbeek, P., Lloyd, M., et al. (2013). Teaching Teachers for the Future (TTF) Project TPACK Survey: Summary of the Key Findings. Australian Educational Computing, Special Edition: Teaching Teachers for the Future Project, 27(3), 13-25.

Government of South Australia. Building a Stronger South Australia: High Quality Education. Retrieved from http://stronger.sa.gov. au/wp-content/uploads/2013/11/building_a_stronger_sa-high_ quality_education.pdf.

Gronn, D., Romeo, G., \& Sheely, S. (2013). TTF@ACU: Our story. Australian Educational Computing, Special Edition: Teaching Teachers for the Future Project., 27(3), 63-68.

Heck, D., \& Sweeney, T. (2013). Using most significant change stories to document the impact of the teaching teachers for the future project: An Australian teacher education story. Australian Educational Computing, Special Edition: Teaching Teachers for the Future Project, 27(3), 36-47.

Henderson, M., Cerovac, M., Bellis, N., \& Lancaster, G. (2013). Collaborative inquiry: Building pre-service teachers' capacity for ICT pedagogical integration. Australian Educational Computing, Special Edition: Teaching Teachers for the Future Project., 27(3), 69-75.

Jamieson-Proctor, R., Finger, G., Cavanagh, R., Albion, P., Fitzgerald, R., Bond, T., \& Grimbeek, P. (2013). Development of the TPACK Survey. Australian Educational Computing, Special Edition: Teaching Teachers for the Future Project., 27(3), 26-35.

Kearney, M., \& Maher, D. (2013). Mobile learning in maths teacher education: Driving pre-service teachers' professional development. Australian Educational Computing, Special Edition: Teaching Teachers for the Future Project., 27(3), 76-84.

Lloyd, M. (2013a). Troubled times in teacher education in Australia: 2012-2013. OLT National Teaching Report. Retrieved from http://www.olt.gov.au/resource-troubled-times-Australian-teachereducation.

Lloyd, M. (2013b). Audit of agencies impacting on course design. Finding the balance Managing synergies and tensions in the whole-of-course design. Report for OLT National Fellowship.

Lloyd, M. (2014). ICT in the age of AITSL. Paper to be presented at ACEC2014, Adelaide, September-October.

Lloyd, M., \& Mukherjeee, M. (2013). Tell me what you see: Preservice teachers' perceptions of exemplary digital pedagogy.
Australian Educational Computing, Special Edition: Teaching Teachers for the Future Project., 27(3), 85-94.

Mishra, P., \& Koehler, M. J. (2006). Technological Pedagogical Content Knowledge: A framework for teacher knowledge. Teachers College Record, 108, 1017-1054.

Mishra, P., \& Koehler, M. J. (2007). Technological Pedagogical Content Knowledge (TPCK): Confronting the Wicked Problems of Teaching with Technology. Paper presented at the Society for Information Technology and Teacher Education International Conference 2007, San Antonio, TX.

New South Wales Government Education and Communities. (2014). Great Teaching: Inspired Learning. Retrieved from http://www. dec.nsw.gov.au/our-services/schools/great-teaching-inspiredlearning.

Niess, M. L. (2011). Investigating TPACK: Knowledge growth in teaching with technology. Journal of Educational Computing Research, 44(3), 299-317.

Sang, G., Valcke, M., van Braak, J., \& Tondeur, J. (2010). Student teachers' thinking processes and ICT integration: Predictors of prospective teaching behaviours with educational technology. Computers \& Education, 54, 103-112.

Shulman, L. S. (1986). Those who understand: Knowledge growth in teaching. Educational Researcher, 15(2), 4-14.

Shulman, L. S. (1987). Knowledge and teaching: Foundations of the new reform. Harvard Educational Review, 57(1), 1-22.

Smith, A. E., \& Humphreys, M. S. (2006). Evaluation of unsupervised semantic mapping of natural language with leximancer concept mapping. Behavior Research Methods, 38(2), 262-279.

Sweeney, T., \& Drummond, A. (2013). How Prepared are our Preservice Teachers to Integrate Technology? A Pilot Study. Australian Educational Computing, Special Edition: Teaching Teachers for the Future Project., 27(3), 117-123.

Teach for Australia. (2014). Teach for Australia. Retrieved from http://www.teachforaustralia.org/.

Teacher Education Ministerial Advisory Group. (2014). Teacher Education Ministerial Advisory Group Issues Paper. Retrieved from http://www.studentsfirst.gov.au/teacher-education-mini sterial-advisory-group.

Tearle, P., \& Golder, G. (2008). The use of ICT in the teaching and learning of physical education in compulsory education: How do we prepare the workforce of the future? European Journal of Teacher Education, 31(1), 55-72.

Thompson, A. D., \& Mishra, P. (2007). Breaking news: TPCK becomes TPACK! Journal of Computing in Teacher Education, 24(2), 38-64.

Tondeur, J., van Braak, J., Sang, G., Voogt, J., Fisser, P., \& Ottenbreit-Leftwich, A. (2012). Preparing pre-service teachers to integrate technology in education: A synthesis of qualitative evidence. Computers \& Education, 59(1), 134-144.

Victoria Department of Education and Early Childhood Development. (2013). From New Directions to Action: World class teaching and school leadership. Retrieved from http://www.education.vic. gov.au/about/department/pages/teachingprofession.aspx.

Voogt, J., Fisser, P., Pareja Roblin, N., Tondeur, J., \& van Braak, J. (2013). Technological Pedagogical Content Knowledge-A review of the literature. Journal of Computer Assisted learning, 29(2), 109-121. 